\title{
Knowledge, Attitude and Practices regarding Cardiovascular Diseases among people of Pakhribas municipality of Eastern Nepal.
}

\author{
Manisha Shrestha', Prajjwal Pyakurel ${ }^{2}$, Kamlesh Prasad Yadav ${ }^{2}$, Sweta Singh ${ }^{1}$, Soumya \\ Priyadarshini' ${ }^{1}$, Bolbam Rajak', Aditya Sinha', Aprajita Aprajita', Ira Kumari', Narendra Mohan Jha', \\ Netra Prassan', Saloni Tripathi ${ }^{1}$, Sanchari Banerjee ${ }^{1}$, Shaurya Shaurya ${ }^{1}$, Anup Ghimire ${ }^{2}$
}

'Bachelor of Medicine, Bachelor of Surgery (MBBS), B.P. Koirala Institute of Health Sciences, Dharan, Nepal.

${ }^{2}$ School of Public Health and Community Medicine, B.P. Koirala Institute of Health Sciences, Dharan, Nepal.

\section{Corresponding Author:}

Manisha Shrestha

Bachelor of Medicine, Bachelor of Surgery, B.P. Koirala Institute of Health Sciences, Dharan, Nepal.

E-mail: shrestham1997@gmail.com

ORCID ID NO: https://orcid.org/0000-0001-8268-1687

Cite this article as: Shrestha M, Pyakurel P, Yadav KP, et al. Knowledge, Attitude and Practices regarding Cardiovascular Diseases among people of Pakhribas municipality of Eastern Nepal: A mixed method study. Nepalese Heart Journal 2020; Vol 17 (1), 33-39

Submitted date: $14^{\text {th }}$ December 2019

Accepted date: $14^{\text {th }}$ April 2020

\section{Abstract}

Background and Aims: Cardiovascular diseases (CVDs) are the leading cause of death globally with 17.9 million deaths in 2016. Nepal is facing a high burden of non-communicable diseases (NCDs) with 66\% of people dying from NCDs in 2018. In this study, we aim to assess the knowledge, attitude and practice regarding CVDs among people of Pakhribas Municipality in Eastern Nepal. Methods: Observational cross-sectional study was conducted among residents of Pakhribas Municipality in eastern Nepal from $9^{\text {th }}$ December to $22^{\text {nd }}$ December 2018. We recruited a convenient sample of 458 permanent residents of Pakhribas municipality. A semi-structured questionnaire based on the CARRF-KL scale survey for knowledge, attitude and practice (after thorough literature review) was used to elicit the information. Descriptive and thematic analysis was done. Result: Fifty-five percent of the respondents belonged to the age group of 30-60 years. Half of the respondents were females. Janjati community was the most dominant ethnicity. One-fourth of the participants were illiterate. The knowledge was found to be average with only $51.5 \%$ realizing that family history of CVDs increases the risk of CVDs. Similarly, $46 \%$ didn't know that coronary heart disease could be prevented. The attitude was found to be good with $90.4 \%, 93.6 \%$ and $90.6 \%$ respectively stating that they will exercise more, change eating habits and quit smoking if they had CVDs. Regarding practices, people visit traditional healers when they are ill and drink alcohol to fight cold despite knowing it as a risk factor for CVDs. Conclusion: The knowledge of people of Pakhribas Municipality regarding CVD was average. However, the attitude was good. Regarding the practice, people have mixed practices.

Keywords: Attitude; CVD; Knowledge; Practice.

DOI: https://doi.org/10.3126/njh.v17i1.28806

\section{Introduction}

Cardiovascular diseases (CVDs) are the leading cause of death globally. Around 17.9 million people died from CVDs in 2016, representing $31 \%$ of all global death. Among these three-quarters of CVD death take place in low and middle-income countries. ${ }^{1}$ South
Asian countries have an increasing trend of risk factors for coronary heart disease (CHD) along with their economic development. ${ }^{2}$ The deaths due to Non Communicable Diseases (NCDs: cardiovascular disease, diabetes, cancer and respiratory disease) have increased from $60 \%$ in 2014 to $66 \%$ of in 2018 of all deaths in $\mathrm{Nepal}^{3}$.

(a) Nepalese Heart Journal. Nepalese Heart Journal retain copyright and works is simultaneously licensed under Creative Commons Attribution License CC - By 4.0 that allows others to share the work with an acknowledge of the work's authorship and initial publication in this journal 
Multiple studies conducted all over the world reveal the inadequate level of knowledge, attitude, and practice (KAP) regarding CVDs at the population level and also highlight the importance of boosting the KAP level in order to reduce the burden of CVDs. ${ }^{4,5,6}$ A study from Kathmandu reported that nearly half of the study population had poor knowledge on CVDs. ${ }^{7}$ However, few studies have assessed the KAP in Nepal and none in the eastern part of Nepal. We aim to assess the KAP on CVDs in the people of Pakhribas Municipality in Eastern Nepal.

\section{Methods}

Our investigation of knowledge, attitudes and practices about CVD was a community based observational cross-sectional study conducted among the residents of Pakhribas municipality in the Eastern region of Nepal. Pakhribas is a municipality of Dhankuta District of Province No.1 with a population of $22,078 .^{8}$ All the permanent residents of Pakhribas municipality of Eastern Nepal were recruited in the study. We recruited a sample of 458 participants using the convenient sampling technique. Those who were $\geq 18$ years and gave consent were included in the study. Mentally retarded individuals were excluded from the study.

Bachelor of Medicine, Bachelor of Surgery (MBBS) thirdyear students were trained to obtain data for 3 days. Standardized questionnaire in the form of the Cardiovascular Disease Risk Factor Knowledge Level (CARRF-KL) scale for the knowledge section, ${ }^{9}$ whereas a thorough literature review was done to formulate the questions for attitude and practice portion of the questionnaire. All the items in the questionnaire were designed to require a response in the form of "YES", "NO" and "DON'T KNOW". In a similar study from the available literature (Vaidya et al), ${ }^{7}$ considering the percentage score of practice i.e. $48 \%$ sample size was calculated with prevalence as 48 , compliment of prevalence as 52 and permissible error at $10 \%$ as 4.8 . The sample size obtained was 416 . Considering $10 \%$ nonresponse rate the final sample size was 458 .

We interviewed the participants on knowledge using a CARRF-KL scale. ${ }^{9}$ There were 28 questionnaires for assessments of knowledge. We grouped these questions in eight different groups. Question 1-4: risk factors \& prevention of CVD, 5-7: Knowledge of correlation between smoking and CVDs, 8-13: Knowledge of diet associated with heart health, 14-17: Exercise and its correlation with heart health, 18-19: Stress and its correlation with heart health, 20-22: Knowledge of blood pressure, 23-26: Knowledge of cholesterol, and 27-28: Diabetes and its relation with heart health. The questionnaire on attitude and practice was developed after a thorough literature review. The validity of the questionnaire was maintained by translating and back translating the questions. The pre-test was done among $10 \%$ of the total sample in a similar community in the Dharan Sub-metropolitan city.

Two Focus Group Discussion (FGDs) were conducted each with 10-12 participants, in two wards of Pakhribas municipality. The FGDs explored practice for CVD. We used semi-structured questionnaire in the Nepali language. The moderator asked open-ended questions to the participants about their opinion and probed for in-depth information. The FGDs lasted for forty-five minutes to one hour and were recorded. The ethical approval was obtained from the Institutional Review Committee (IRC) of B.P. Koirala Institute of Health Sciences, Dharan, Nepal. The data were entered in the Microsoft Excel spreadsheet and converted into SPSS Version 17 for statistical analysis. Data were summarized using numbers and percentages using frequency distribution tables. FGDs were transcribed. The investigator reviewed the full transcripts and compared them with original recordings. Data were analyzed using a thematic analysis framework focused on identifying patterned meaning across a dataset.
Operational Definition

Noncommunicable diseases (NCDs), also known as chronic diseases, tend to be of long duration and are the result of a combination of genetic, physiological, environmental and behavioral factors. ${ }^{10}$

Mental retardation: Mental retardation is a condition of arrested or incomplete development of the mind, which is especially characterized by impairment of skills manifested during the developmental period, which contribute to the overall level of intelligence, i.e. cognitive, language, motor, and social abilities. ${ }^{11}$

Skilled worker: Complicated work requiring long training e.g. carpenter, mason, mechanic, driver, telephone operator etc. ${ }^{12}$

Semi-skilled worker: Work requiring some training e.g. assistant operator or electrician, factory workers, laboratory attendant, bookbinder, waiter or bearer, etc. ${ }^{12}$

Unskilled worker: Work requiring neither education nor training and no independent Judgment e.g. peon, watchman, Durban, cleaner, sweeper, loader, helper, woodcutter etc..$^{12}$

Regarding the level of knowledge, attitude and practice of CVDs among the respondents we have classified the results on the basis of the percentage of correct responses as follows:

$<50 \%$ : Poor

50-70\%: Average

$>70 \%$ : Good

\section{Results}

Fifty-five percent (55\%) of the respondents were 30-60 years of age. Half of the respondents were females. Janjati community was the most dominant ethnicity (47\%). About fifty percent $(50.6 \%)$ had semi-skilled professions. One-fourth of the participants were illiterate (Table 1)

Table 1: Socio-demographic characteristics of study participants $(n=468)$

\begin{tabular}{|c|c|c|c|}
\hline Characteristics & Category & $\begin{array}{l}\text { Fre- } \\
\text { quency }\end{array}$ & $\begin{array}{l}\text { Per- } \\
\text { centage }\end{array}$ \\
\hline \multirow[t]{3}{*}{ Age } & $<30$ years & 157 & 33.5 \\
\hline & $30-60$ years & 259 & 55.3 \\
\hline & $>60$ years & 52 & 11.1 \\
\hline $\begin{array}{l}\text { Mean age } \pm S D \text {, } \\
\text { in years }\end{array}$ & \multicolumn{3}{|c|}{$37.7 \pm 14.9$ years } \\
\hline \multirow[t]{2}{*}{ Gender } & Male & 228 & 48.7 \\
\hline & Female & 240 & 51.3 \\
\hline \multirow[t]{3}{*}{ Religion } & Hindu & 349 & 74.6 \\
\hline & Buddhist & 113 & 24.1 \\
\hline & Christian & 06 & 1.3 \\
\hline \multirow[t]{5}{*}{ Ethnicity } & Janjati & 220 & 47.0 \\
\hline & Brahmin/Chhetri & 126 & 26.9 \\
\hline & Dalit & 91 & 19.4 \\
\hline & Madhesi & 17 & 3.6 \\
\hline & Others (Newari, Thakali) & 14 & 3.0 \\
\hline
\end{tabular}




\begin{tabular}{|c|c|c|c|}
\hline \multirow[t]{4}{*}{ Occupation } & Unskilled & 122 & 26.1 \\
\hline & Semiskilled & 237 & 50.6 \\
\hline & Skilled & 36 & 7.7 \\
\hline & Unemployed & 73 & 15.6 \\
\hline \multirow[t]{4}{*}{ Education } & Illiterate & 117 & 25.0 \\
\hline & Primary Education & 90 & 19.2 \\
\hline & $\begin{array}{l}\text { Secondary } \\
\text { Education }\end{array}$ & 201 & 42.9 \\
\hline & Tertiary Education & 60 & 12.8 \\
\hline \multirow[t]{4}{*}{ Marital status } & Unmarried & 77 & 16.5 \\
\hline & Married & 374 & 79.9 \\
\hline & Widowed & 15 & 3.2 \\
\hline & Divorced & 2 & 4 \\
\hline \multirow{2}{*}{$\begin{array}{l}\text { No. of family } \\
\text { member } \pm \text { SD }\end{array}$} & $\leq 5$ members & 305 & 65.2 \\
\hline & $>5$ members & 163 & 34.8 \\
\hline $\begin{array}{l}\text { Mean Family } \\
\text { member } \pm \text { SD }\end{array}$ & \multicolumn{3}{|c|}{$5.27 \pm 2.4$} \\
\hline $\begin{array}{l}\text { Mean family } \\
\text { income } \pm S D \text {, } \\
\text { (NRS) }\end{array}$ & \multicolumn{3}{|c|}{$22701.9 \pm 23$} \\
\hline
\end{tabular}

\section{Knowledge on CVDs}

Forty percent of the participants $(40.4 \%)$ perceived that an individual suffering from heart disease could be asymptomatic. About fifty-one percent $(51.5 \%)$ of the respondents knew that a family history of CVDs was a risk factor for CVDs in the future. About sixtythree percent (62.8\%) said elderly people were at higher risk of CVDs, while $66 \%$ said CVDs could be prevented. Regarding knowledge on smoking, eighty-eight percent regarded smoking as a preventable cause of death. Similarly, eighty-seven percent considered smoking as a risk factor for heart diseases. Eighty-three percent of the respondents supported the view that by quitting to smoke, the risk of developing heart disease is reduced.

Ninety-three percent stated eating two to three portions of fruits and two portions of vegetables a day was beneficial and about fortyeight percent considered eating red meat more than three times a week as harmful. Additionally, eighty percent knew that eating salty food was associated with increased blood pressure. More than onethird did not know that fatty meals increase cholesterol levels in the blood. About seventy percent knew low carbohydrate and lowfat diet as beneficial for heart health. About seventy-seven percent of the respondents agreed that overweight individuals have a higher risk of heart disease. Similarly, ninety percent believed that regular exercise reduces the risk of CVDs. About twenty-one percent thought that exercising in gyms was the only way to reduce the risk whereas seventy-eight percent of the respondents considered slow walking and wandering to reduce the risk of heart disease.

Regarding knowledge about blood pressure, seventy-five percent were aware that high blood pressure was a risk factor for heart disease and seventy-two percent perceived that controlled blood pressure reduces the risk of heart disease. Fifty-five percent agreed that the medications for hypertension needed to be taken throughout life. Fifty- six percent responded that they didn't know that cholesterol is a risk factor for heart disease. Ninety-one percent and eighty-nine percent didn't know the importance of good and bad cholesterol respectively. Additionally, seventy percent of them believed that every person with high cholesterol is prescribed medicine. Sixty-one percent of the respondents considered diabetes as a risk factor for heart diseases and fifty-seven percent, believed the risk could be reduced with glucose control. (Table 2)

Overall, the age group of $>60$ years showed relatively less knowledge regarding the risk factors and men had better knowledge of cardiovascular diseases.

Table 2: Knowledge regarding CVDs

\begin{tabular}{|c|c|c|c|}
\hline Question & Category & Frequency & Percentage \\
\hline \multirow{4}{*}{$\begin{array}{l}\text { K1 - Person always } \\
\text { realizes if he/she has } \\
\text { heart disease }\end{array}$} & No & 189 & 40.4 \\
\hline & Yes & 145 & 31.4 \\
\hline & Don't Know & 134 & 28.6 \\
\hline & Total & 468 & 100.0 \\
\hline \multirow{4}{*}{$\begin{array}{l}\mathrm{K} 2-\text { Family history } \\
\text { of } \\
\text { CVD increases } \\
\text { risk of } \\
\text { Having heart disease }\end{array}$} & No & 94 & 20.1 \\
\hline & Yes & 241 & 51.5 \\
\hline & Don't Know & 133 & 28.4 \\
\hline & Total & 468 & 100.0 \\
\hline \multirow{4}{*}{$\begin{array}{l}\text { K3 - Elderly people } \\
\text { are at higher risk of } \\
\text { having heart disease }\end{array}$} & No & 85 & 18.2 \\
\hline & Yes & 294 & 62.8 \\
\hline & Don’t Know & 89 & 19.0 \\
\hline & Total & 468 & 100.0 \\
\hline \multirow{4}{*}{$\begin{array}{l}\text { K4 - CVD can be } \\
\text { prevented }\end{array}$} & No & 38 & 8.1 \\
\hline & Yes & 307 & 65.6 \\
\hline & Don’t Know & 123 & 26.3 \\
\hline & Total & 468 & 100.0 \\
\hline \multirow{4}{*}{$\begin{array}{l}\text { K5 - Smoking is } \\
\text { preventable cause of } \\
\text { death and diseases in } \\
\text { our country }\end{array}$} & No & 28 & 6.0 \\
\hline & Yes & 410 & 87.6 \\
\hline & Don't Know & 30 & 6.4 \\
\hline & Total & 468 & 100.0 \\
\hline \multirow{4}{*}{$\begin{array}{l}\text { K6 - Smoking is a } \\
\text { risk factor for heart } \\
\text { disease }\end{array}$} & No & 24 & 5.1 \\
\hline & Yes & 408 & 87.2 \\
\hline & Don't Know & 36 & 7.7 \\
\hline & Total & 468 & 100.0 \\
\hline \multirow{4}{*}{$\begin{array}{l}\mathrm{K} 7 \text { - Risk of devel- } \\
\text { oping heart disease } \\
\text { is reduced when } \\
\text { smoking is stopped }\end{array}$} & No & 23 & 4.9 \\
\hline & Yes & 390 & 83.3 \\
\hline & Don't Know & 55 & 11.8 \\
\hline & Total & 468 & 100.0 \\
\hline
\end{tabular}




\begin{tabular}{|c|c|c|c|}
\hline \multirow{4}{*}{$\begin{array}{l}\mathrm{K} 8-\mathrm{It} \text { is beneficial } \\
\text { to eat } 2-3 \text { portions } \\
\text { of food and } 2 \text { por- } \\
\text { tions of vegetables } \\
\text { daily }\end{array}$} & No & 13 & 2.8 \\
\hline & Yes & 435 & 92.9 \\
\hline & Don't Know & 20 & 4.3 \\
\hline & Total & 468 & 100.0 \\
\hline \multirow{4}{*}{$\begin{array}{l}\mathrm{K} 9-\mathrm{It} \text { is harmful } \\
\text { to eat red meat } \\
\text { more than thrice a } \\
\text { week }\end{array}$} & No & 99 & 21.2 \\
\hline & Yes & 220 & 47.0 \\
\hline & Don't Know & 149 & 31.8 \\
\hline & Total & 468 & 100.0 \\
\hline \multirow{4}{*}{$\begin{array}{l}\text { K10 - Eating } \\
\text { excess salty food } \\
\text { leads to increase in } \\
\text { blood pressure }\end{array}$} & No & 24 & 5.1 \\
\hline & Yes & 372 & 79.5 \\
\hline & Don't Know & 72 & 15.4 \\
\hline & Total & 468 & 100.0 \\
\hline \multirow{4}{*}{$\begin{array}{l}\text { K11 - Fatty meals } \\
\text { do not increase the } \\
\text { cholesterol level in } \\
\text { blood }\end{array}$} & No & 123 & 26.3 \\
\hline & Yes & 161 & 34.4 \\
\hline & Don't Know & 184 & 39.3 \\
\hline & Total & 468 & 100.0 \\
\hline \multirow{4}{*}{$\begin{array}{l}\mathrm{K} 12-\text { Fats that } \\
\text { are solid at room } \\
\text { temperature are } \\
\text { beneficial for heart } \\
\text { health }\end{array}$} & No & 160 & 34.2 \\
\hline & Yes & 97 & 20.7 \\
\hline & Don't Know & 211 & 45.1 \\
\hline & Total & 468 & 100.0 \\
\hline \multirow{4}{*}{$\begin{array}{l}\text { K13 - A low carbo- } \\
\text { hydrate and low fat } \\
\text { diet is beneficial for } \\
\text { heart health }\end{array}$} & No & 22 & 4.7 \\
\hline & Yes & 331 & 70.7 \\
\hline & Don’t Know & 115 & 24.6 \\
\hline & Total & 468 & 100.0 \\
\hline \multirow{4}{*}{$\begin{array}{l}\text { K14-Overweight } \\
\text { individuals have } \\
\text { higher risk of heart } \\
\text { disease }\end{array}$} & No & 36 & 7.7 \\
\hline & Yes & 361 & 77.1 \\
\hline & Don’t Know & 71 & 15.2 \\
\hline & Total & 468 & 100.0 \\
\hline \multirow{4}{*}{$\begin{array}{l}\text { K15 - Regular ex- } \\
\text { ercise reduces risk } \\
\text { of heart disease }\end{array}$} & No & 11 & 2.4 \\
\hline & Yes & 424 & 90.6 \\
\hline & Don’t Know & 33 & 7.1 \\
\hline & Total & 468 & 100.0 \\
\hline \multirow{4}{*}{$\begin{array}{l}\text { K16 - Risk can be } \\
\text { reduced by exercis- } \\
\text { ing only in gym }\end{array}$} & No & 292 & 62.4 \\
\hline & Yes & 101 & 21.6 \\
\hline & Don’t Know & 75 & 16.0 \\
\hline & Total & 468 & 100.0 \\
\hline
\end{tabular}

K17 - Slow walking and wandering are also considered as exercise

axe

K18 - Stress,
sorrow and burden
increases risk of
ases risk of heart disease

(n)

\section{K19 - Blood} pressure increases under stressful conditions

(1)

\begin{tabular}{|lll|}
\hline No & 57 & 12.2 \\
\hline Yes & 363 & 77.6 \\
\hline $\begin{array}{l}\text { Don't } \\
\text { Know }\end{array}$ & 48 & 10.3 \\
\hline Total & 468 & 100.0 \\
\hline
\end{tabular}

$\begin{array}{lll}\text { No } & 25 & 5.3\end{array}$

$\begin{array}{lll}\text { Yes } & 373 & 79.7\end{array}$

Don't $\quad 70 \quad 15.0$

Know

$\begin{array}{lll}\text { Total } & 468 & 100.0\end{array}$

$\begin{array}{lll}\text { No } & 7 & 1.5 \\ \text { Yes } & 381 & 81.4\end{array}$

K20 - High blood pressure is a risk factor for heart disease

\begin{tabular}{lcc} 
Don't & 18 & 15.0 \\
Know & & 100.0 \\
\hline Total & 468 & 108
\end{tabular}

$\begin{array}{lll}\text { Total } & 468 & 100.0\end{array}$

\begin{tabular}{llll} 
disease & $\begin{array}{l}\text { Don't } \\
\text { Know }\end{array}$ & 105 & 22.4 \\
\hline & Total & 468 & 100.0 \\
\hline $\begin{array}{l}\text { K21 - Blood pres- } \\
\begin{array}{l}\text { sure control reduces } \\
\text { the risk of heart } \\
\text { disease }\end{array}\end{array}$ & No & 13 & 2.8 \\
& Yes & 336 & 71.8 \\
& $\begin{array}{l}\text { Don't } \\
\text { Know }\end{array}$ & 119 & 25.4 \\
& Total & 468 & 100.0
\end{tabular}

K22 - Hypertension medications should be used for lifetime

Kes- High choles-

\begin{tabular}{|lll|}
\hline No & 69 & 14.7 \\
\hline Yes & 255 & 54.5 \\
\hline Don`t & 144 & 30.8 \\
\hline Know & & \\
\hline
\end{tabular}

K23 - High cholesterol is a risk factor for heart disease

Total $\quad 468$

$\begin{array}{lll}\text { No } & 4 & 0.9\end{array}$

$\begin{array}{lll}\text { Yes } & 205 & 43.8\end{array}$

\begin{tabular}{|lcc|}
\hline $\begin{array}{l}\text { Don’t } \\
\text { Know }\end{array}$ & 259 & 55.3 \\
\hline Total & 468 & 100.0 \\
\hline
\end{tabular}

\begin{tabular}{|c|c|c|c|}
\hline \multirow{4}{*}{$\begin{array}{l}\mathrm{K} 24-\text { There is a } \\
\text { risk of heart disease } \\
\text { if good cholesterol } \\
\text { (HDL) is high }\end{array}$} & No & 20 & 4.3 \\
\hline & Yes & 24 & 5.1 \\
\hline & $\begin{array}{l}\text { Don't } \\
\text { Know }\end{array}$ & 424 & 90.6 \\
\hline & Total & 468 & 100.0 \\
\hline
\end{tabular}




\begin{tabular}{|c|c|c|c|}
\hline \multirow{4}{*}{$\begin{array}{l}\mathrm{K} 25 \text { - There is a } \\
\text { risk of heart disease } \\
\text { if bad (LDL) cho- } \\
\text { lesterol is high }\end{array}$} & No & 12 & 2.6 \\
\hline & Yes & 37 & 7.9 \\
\hline & $\begin{array}{l}\text { Don't } \\
\text { Know }\end{array}$ & 419 & 89.5 \\
\hline & Total & 468 & 100.0 \\
\hline \multirow{4}{*}{$\begin{array}{l}\text { K26 - Every } \\
\text { person with high } \\
\text { cholesterol is given } \\
\text { medicine }\end{array}$} & No & 42 & 9.0 \\
\hline & Yes & 99 & 21.2 \\
\hline & $\begin{array}{l}\text { Don't } \\
\text { Know }\end{array}$ & 327 & 69.9 \\
\hline & Total & 468 & 100.0 \\
\hline \multirow{4}{*}{$\begin{array}{l}\mathrm{K} 27-\text { Diabetes is a } \\
\text { risk factor for heart } \\
\text { disease }\end{array}$} & No & 30 & 6.4 \\
\hline & Yes & 283 & 60.5 \\
\hline & $\begin{array}{l}\text { Don't } \\
\text { Know }\end{array}$ & 155 & 33.1 \\
\hline & Total & 468 & 100.0 \\
\hline \multirow{4}{*}{$\begin{array}{l}\text { K28 - The risk can } \\
\text { be reduced in dia- } \\
\text { betic patients with } \\
\text { glucose control }\end{array}$} & No & 21 & 4.5 \\
\hline & Yes & 268 & 57.3 \\
\hline & $\begin{array}{l}\text { Don't } \\
\text { Know }\end{array}$ & 179 & 38.2 \\
\hline & Total & 468 & 100.0 \\
\hline
\end{tabular}

Attitude regarding CVDs

One-third of the respondents believed they could not get CVDs. Most of them (93\%) said they would go for regular medical checkups if they had CVD. Ninety percent of the respondents would exercise more, 94\% would change their eating habits and 91\% would quit smoking, if they had CVD. (Table 3)

Table 3: Attitude regarding CVDs

\begin{tabular}{|c|c|c|c|}
\hline Question & Category & Frequency & Percentage \\
\hline \multirow{4}{*}{$\begin{array}{l}\text { A } 29-\text { Do you } \\
\text { think you can get } \\
\text { CVD? }\end{array}$} & No & 152 & 32.5 \\
\hline & Yes & 223 & 47.6 \\
\hline & Don't Know & 93 & 19.9 \\
\hline & Total & 468 & 100.0 \\
\hline \multirow{4}{*}{$\begin{array}{l}\text { A } 30 \text { - If you had } \\
\text { CVD, would you } \\
\text { go for regular } \\
\text { medical checkup? }\end{array}$} & No & 22 & 4.7 \\
\hline & Yes & 434 & 92.7 \\
\hline & Don't Know & 12 & 2.6 \\
\hline & Total & 468 & 100.0 \\
\hline \multirow{4}{*}{$\begin{array}{l}\text { A31 - If you had } \\
\text { CVD, would you } \\
\text { like to exercise } \\
\text { more? }\end{array}$} & No & 24 & 5.1 \\
\hline & Yes & 423 & 90.4 \\
\hline & Don't Know & 21 & 4.5 \\
\hline & Total & 468 & 100.0 \\
\hline
\end{tabular}

\begin{tabular}{l|lll}
$\begin{array}{l}\text { A32 - If you had } \\
\text { CVD, would you }\end{array}$ & No & 11 & 2.4 \\
$\begin{array}{l}\text { like to change your } \\
\text { eating habits? }\end{array}$ & Yes & 438 & 93.6 \\
& Don't Know & 19 & 4.1 \\
\hline Total & 468 & 100.0 \\
\hline $\begin{array}{l}\text { A33 - If you had } \\
\text { CVD, would you }\end{array}$ & No & 11 & 2.4 \\
$\begin{array}{l}\text { like to quit } \\
\text { smoking? }\end{array}$ & Yes & 424 & 90.6 \\
& Don't Know & 33 & 7.1 \\
\hline & Total & 468 & 100.0
\end{tabular}

Practice regarding CVDs

Practice regarding CVDs was not quantified in terms of data. However, two FGDs were conducted in two different wards of Pakhribas municipality to assess the KAP of the participants. The majority of the participants responded to seeking medical attention when they had heart disease. They knew that increased blood pressure, increased salt intake, alcohol consumption and smoking increased the risk of CVDs. Most of the participants follow the doctor's advice. The result of FGDs is summarized as follows: (Figure 1)

Figure 1: Thematic analysis of KAP regarding CVD

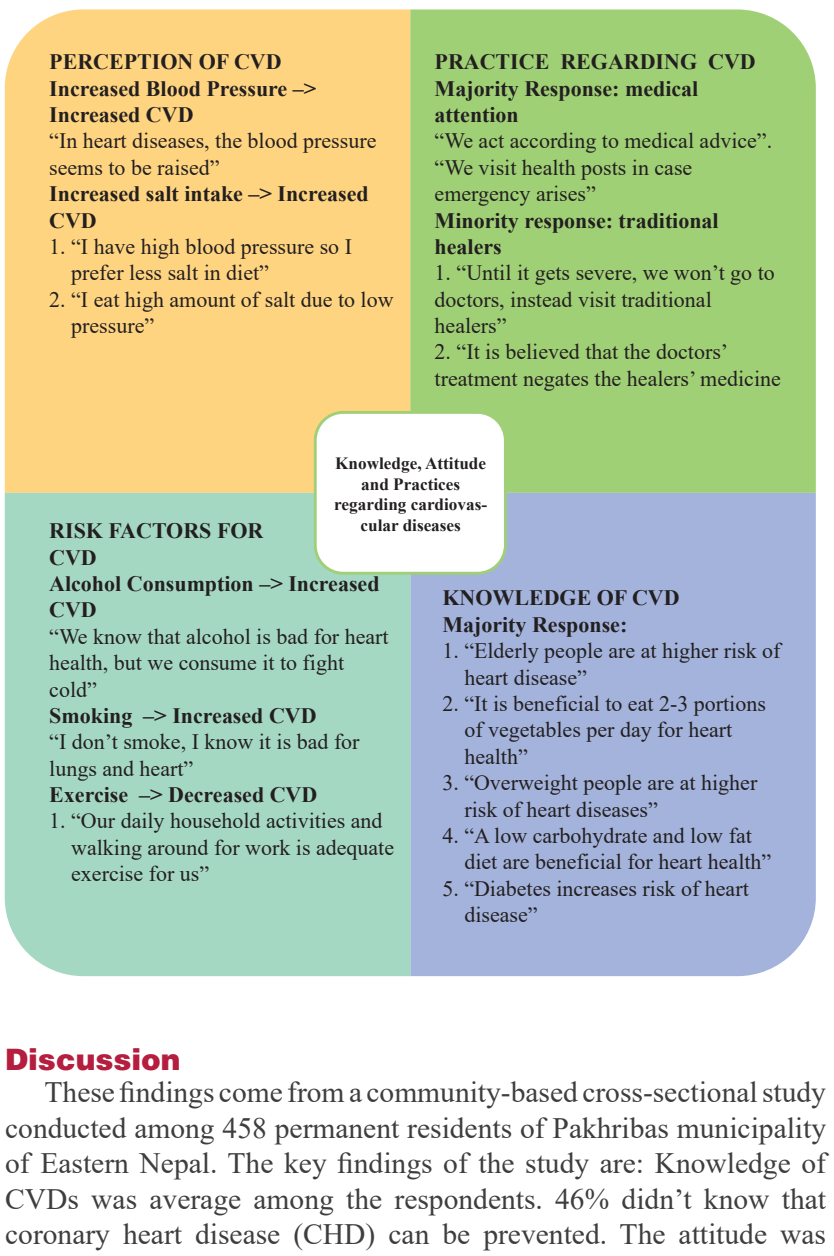


found to be good with $90.4 \%, 93.6 \%$ and $90.6 \%$ respectively saying that they will exercise more, will change the eating habits and will quit smoking if they had CVDs. Regarding the practice, people still drink alcohol to protect against the cold despite knowing that it is a risk factor for CVD.

In our study $51.3 \%$ of participants were female and $48.7 \%$ were male. A similar study was done by Vaidya et al. in Central Nepal showed a preponderance of female population. ${ }^{7}$ This could be due to the fact that most Nepalese women are house maker and look after their house and family hence could be easily available during household surveys. Most of the participants belonged to Janjati (47\%) ethnicity followed by Brahmin/Chhetri (26.9\%). A comparable study done in central Nepal showed Brahmin/Chhetri ethnicity comprises $62.8 \%$ followed by Newars $(24.96 \%){ }^{7}$ The difference in this finding could be due to the different ethnic groups inhabiting different geographical areas of Nepal. The majority of participants attended a secondary level of education (42.9\%). A similar study done in Turkey and Nepal showed most of the participants attained primary education $42 \%$ (Turkey) and $31.6 \%$ (Nepal) respectively. ${ }^{7,13}$

The respondents of our study had better knowledge about smoking as a risk factor for CVD (87.2\%) in comparison to a similar study done in the rural community of Lahore where only $63.6 \%$ of the respondents had the knowledge. ${ }^{14}$ About fifty one percent $(51.5 \%)$ of our respondents realized that family history of CVDs increases the risk of heart diseases which was comparable with the results of a similar study done in Lahore where $43.6 \%$ of the participants had the knowledge that CVD cases are hereditary. ${ }^{14}$

With an increase in the prevalence of NCDs in recent years, knowledge in the Nepalese population has been increasing.? However, due to some unknown reasons, the elderly population, who are at greater risk of having CVD lack adequate knowledge. A similar finding was found in our study where the age group of $>60$ years showed relatively less knowledge regarding the risk factors. This finding is supported by a study done in the Canadian population with age $\geq 65$ years were less able to recall important cardiovascular disease risk factors. ${ }^{15}$

Men had better knowledge of heart disease; however, their attitude was similar to those reported by women. One major factor for the gender discrepancy in our study is that more women (30.8\%) than men $(18.9 \%)$ lacked education, which is alarming. In fact, illiteracy is one of the main risk factors along with behavioral factors in rural/urban Asian Indian women. ${ }^{16}$ In our study, it was found that the participants' knowledge levels about risk factors for CVDs are medium which is comparable to the Turkish population. ${ }^{12}$ Regarding the attitude $92.7 \%$ of them said they would go for regular medical checkups, $90.4 \%$ would exercise more, $93.9 \%$ would change their eating habits and $90.6 \%$ would quit smoking, if they had a CVD. A similar study done in Malaysia showed $81 \%$ would do a regular medical checkup, $94.9 \%$ were willing to exercise, $70.1 \%$ would change eating habit easily and $79.2 \%$ would not smoke or be a passive smoker. ${ }^{17}$

\section{Limitations}

This study was conducted in one of the hilly districts of Nepal hence it cannot be generalized to the whole Nepalese population. Most of the respondents belonged to the ethnic groups Brahmin, Chhetri and Janjati, which are not representative of all caste/ethnic groups in Nepal. In addition to that, we were also within tight constraints of time which limited our study to only reflect the descriptive data that merely reflects the basic understanding of the respondents regarding knowledge, attitude and practice of CVDs rather than quantifying them according to the mean, median or KAP score. We plan to include these thorough analyses in our future studies done in a similar context.
Recommendations

Our research found that residents of Pakhribas municipality had less KAP toward CVDs. Health education programs need to be strengthened in the newly formed federal structure of the government of Nepal at central, provincial and at local levels to create awareness regarding CVDs. Although the constitution of Nepal 2072, addresses health as the basic right of all Nepalese population, people in the rural part of the country still shy away from reaching out to basic health facility for medicines and appropriate management of CVDs, stating that health care providers and infrastructures in their area are not good enough or that it was too costly. ${ }^{18}$ Further study needs to be conducted considering the recently formed federal structure of Nepal including rural, urban and semi-urban regions of Nepal to find out exact KAP regarding CVDs to apply appropriate intervention considering the local context.

\section{Conclusions}

Our study was a community-based cross-sectional study conducted in Pakhribas. The knowledge of people of Pakhribas municipality regarding CVD was average. However, the attitude was good. Among all the participants who identified smoking as a risk factor for CVD, 93.6\% accepted that they would quit smoking if they had CVD. Regarding the practice people have mixed practices.

\section{Acknowledgment}

We would like to acknowledge the B.P. Koirala Institute of Health Sciences, School of Public Health and Community Medicine for providing us the opportunity to conduct this research. We would also like to thank the Chief, Program Coordinator, Supervising Faculty for their guidance and support throughout the research. We would like to thank all the participants who gave us their consent to be a part of this study. Finally, we would also like to thank Nepal Commercial Agriculture Research Program Pakhribas, Dhankuta for providing logistic support during our stay in Pakhribas.

\section{Conflict of Interest: None}

\section{References}

1. WHO.Cardiovasculardiseases(CVDs)[Internet]. 2017. Available from:URL:https://www.who.int/news-room/factsheets/detail/cardiovascular-diseases-(cvds)

2. Reddy KK, Rao AP, Reddy TPK. Socioeconomic status and the prevalence of coronary heart disease risk factors. APJCN2002;11(2):98-103. https://doi.org/10.1046/j.14406047.2002.00267.x. PMid:12074188

3. Department of Health Services, Ministry of Health and Population, Government of Nepal. Annual Report [Internet] 2074/75(2017/18):217. Available from: https://dohs.gov.np/ wp-content/uploads/2019/07/DoHS-Annual-Report-FY-207475-date-22-Ashad-2076-for-web-1.pdf

4. Amarasekara P, Silva A, Swarnamali H, et al. Knowledge, Attitudes and Practices on Lifestyle and Cardiovascular Risk Factors Among Metabolic Syndrome Patients in an Urban Tertiary Care Institute in Sri Lanka. APJPH/APACPH 2015;28 (1 Supp):32S-40S. https://doi.org/10.1177/1010539515612123 PMid:26512029. PMCid:PMC4834136 
5. Dayal B, Singh N. Association between knowledge, attitude and practice on cardiovascular disease among early adults of Lucknow city.AJMS 2018; 11(1):59-65. doi:10.13140/ RG.2.2.25554.66247

6. Mirmiran P, Mohammadi-Nasrabadi F, Omidvar N, et al. Nutritional Knowledge, Attitude and Practice of Tehranian Adults and Their Relation to Serum Lipid and Lipoproteins: Tehran Lipid and Glucose Study. Ann Nutr Metab 2010;56(3):233-240. https://doi.org/10.1159/000288313 PMid:20375546

7. Vaidya A, Aryal UR, Krettek A. Cardiovascular health knowledge, attitude and practice/behaviour in an urbanising community of Nepal: A population-based cross-sectional study from Jhaukhel-Duwakot Health Demographic Surveillance Site. BMJ Open. 2013;3 (10):1-11. https://doi.org/10.1136/bmjopen-2013-002976. PMid:24 157816. PMCid:PMC3808775

8. Pakhribas Municipality [Internet]. Available from: URL: http://www.pakhribasmun.gov.np/en/content/

9. Arikan I, Metintas S, Kalyoncu C, et al.The Cardiovascular Disease Risk Factors Knowledge Level (CARRF-KL) Scale: a validity and reliability study.Türk Kardiyol Dern Ars.2009; 37 (1): $35-40$

10. WHO. Noncommunicable Diseases [Internet]. Available from:URL: https://www.who.int/news-room/fact-sheets /detail/noncommunicable-diseases?fbclid=IwAR3I9JtP01Fmrb QKY0-ft2VuehTe-IC43dKLNPEJhHnI78p_rkcuYfIWtVU

11. WHO, Geneva 1996. ICD-10 Guide for Mental Retardation. Available from: URL: https://www.who.int/mental_health/ media/en/69.pdf
12. Kishore J, Kohli C, Kumar N. Kuppuswamy's Socioeconomic Scale-Update for July 2015. IJoPCCM 2015; 1: 26-28

13. Andsoy II, Tastan S, Iyigun E, Kopp LR. Knowledge and attitudes towards cardiovascular disease in a population of North Western Turkey: a cross-sectional survey.IJCS 2015; 8(1): 115-124

14. Ejaz S et al. Knowledge, Attitude, Practice Regarding Modifiable Risk Factors of Cardiovascular Diseases Among Adults in Rural Community, Lahore. IJSSM 2018; 5(3): 7682. https://doi.org/10.3126/ijssm.v5i3.19902

15. Potvin L, Richard L, Edwards AC. Knowledge of cardiovascular disease risk factors among the Canadian population: relationships with indicators of socioeconomic status. CMAJ 2000; 162 (9 Suppl): S5-S11

16. Pandey RM, Agrawal A, Misra A, et al. Population-based intervention for cardiovascular diseases related knowledge and behaviours in Asian Indian women. IHJ 2013; 65 (1): 40-7. https://doi.org/10.1016/j.ihj.2012.12.019. PMid:23438611 PMCid:PMC3860769

17. Rosediani M, Ranimah Y, Harmy MY. Knowledge, Attitude and Practice on Cardiovascular Disease among Women in North-Eastcoast Malaysia. IJCRIMPH 2012; 4(1): 85-98.

18. Bhattarai S, Parajuli S, Rayamajhi R, et al. Health Seeking Behavior and Utilization of Health Care Services in Eastern Hilly Region of Nepal. JCMSN 2015; 11(2): 8-6. https://doi. org/10.3126/jcmsn.v11i2.13669 